\title{
POWER TO ENJOIN STATE PROSECUTIONS VIOLATIVE OF FEDERALLY PROTECTED RIGHTS
}

In recent years the federal courts have been repeatedly confronted with demands for injunctive relief against state criminal prosecutions. A Negro is arrested on a breach of the peace charge for seeking service in a restaurant. Can he enjoin the prosecution or must he defend the action?

The legal basis of such demands for anticipatory federal jurisdiction is in federal legislation which provides for equitable relief against deprivation of civil rights. The practical basis is the need for a mechanism which will give immediate protection to the exercise of federally guaranteed civil rights: "The battle is for the streets, and on the streets conviction now is worth a hundred times reversal later." 1 The fear is that without anticipatory federal jurisdiction the exercise of civil rights simply may not be worth the trouble. ${ }^{2}$

Against this need stands a traditional policy of federal noninterference with state court proceedings, a policy long expressed both in judicial practice and in a federal statute. This Comment is concerned primarily with the availability of injunctive relief against pending state prosecutions, which, in order to be available, must be consistent with section 2283 of the Judiciary Act, $^{3}$ the federal anti-injunction statute. The precise question is whether either the civil liability provision of the Civil Rights Act of $1871^{4}$ or Title II of the Civil Rights Act of $1964^{5}$ constitutes the congressional authorization required by section 2283 for the staying of state criminal proceedings by the federal courts. ${ }^{8}$

Section 2283 provides: "A court of the United States may not grant an injunction to stay proceedings in a State court except as expressly authorized by Act of Congress, or where necessary in aid of its jurisdiction, or to protect or effectuate its judgments." 7 This federal prohibition, in one form or another, dates back to 1793.8 However, the courts have

1 Amsterdam, Criminal Prosecutions Affecting Federally Guaranteed Civil Rights: Federal Removal and Habeas Corpus Intrisdiction To Abort State Court Trial, 113 U. PA. L. Rev. 793, 801 (1965) [hereinafter cited as Amsterdam].

2 Professor Amsterdam makes a strong case for the necessity of extending anticipatory federal jurisdiction. Amsterdam 794-803.

328 U.S.C. $\$ 2283$ (1964) (quoted in text at note 7 infra). infra).

4 Rev. Stat. \$1979 (1875), 42 U.S.C. \$1983 (1964) (quoted in text at note 24

578 Stat. 243 (1964), 42 U.S.C. $\$ \$ 2000 \mathrm{a}, 2000 \mathrm{a}-6$ (1964).

- Although Title II of the 1964 Civil Rights Act deals only with the right of equal access to public accommodations, while there are many categories of possible claims under the 1871 law, that difference is not particularly relevant to this discussion.

728 U.S.C. $\$ 2283$ (1964).

8 The Judiciary Act of 1793, ch. 22, §5, 1 Stat. 335 provided: "nor shall a writ of injunction be granted to stay proceedings in any court of a state . . " The immediate predecessor to the present statute was the Judiciary Act of 1911 , ch. 231 , $\$ 265$, 36 Stat. 1162 . The 1911 provision differed from $\$ 2283$ in that it did not contain any of the three exception clauses; it contained merely a specific exception for bankruptcy proceedings. 
found a number of statutory "exceptions." In Toucey v. Neze York Life Ins. Co., a 1941 decision, Mr. Justice Frankfurter discussed in detail the cases in which these exceptions were created..$^{10} \mathrm{He}$ suggested that the underlying rationale of the decisions was the impossibility of giving any meaning to the particular statutes involved without finding such exceptions. ${ }^{11}$ The important feature of his analysis is the path by which that conclusion was reached. The analysis puts the question in terms of whether or not the later statute-the possible exception-evinces an unmistakably clear intention to operate as an exception; it does not focus on the underlying purposes of the later statute to see whether these purposes might best be effectuated by finding an exception. This analysis is a response to, and logically follows from, the traditional view which attaches great importance to the policy of federal noninterference. In general the courts have displayed this rather rigid attitude when urged to find possible exceptions under the statute. In Amalgamated Clothing Workers v. Richman Bros. Co., ${ }^{12}$ the Supreme Court characterized the anti-injunction statute as "not a statute conveying a broad general policy for appropriate ad hoc application. Legislative policy is here expressed in a clear cut prohibition qualified only by specifically defined exceptions."13

9314 U.S. 118 (1941). Toncey was decided while the 1911 provision, discussed note 8 supra, was still in force. Because the statute in this form did not contain an exception clause like the first one in the present $\$ 2283$, the courts construed the exceptions as "amendments" to the 1911 statute.

10 His list included: a) The Removal Acts-the original provision was part of the Judiciary Act of 1789, ch. 20, \$12, 1 Stat. 79 (now 28 U.S.C. $\$ \$ 1441-44$ (1964)). Madisonville Traction Co. v. St. Bernard Mining Co., 196 U.S. 239 (1905) ; Dietzsch v. Huidekoper, 103 U.S. 494 (1880). b) The Act of March 3, 1851 (limiting the liability of shipowners)-Rev. Stat. \$4285 (1875) (now 49 Stat. 1480 (1936), 46 U.S.C. $\$ 185$ (1964)), providing that upon the happening of certain contingencies all claims against the owner should cease. Providence \& N.Y.S.S. Co. v. Hill Mfg. Co., 109 U.S. 578, 599 (1883). c) The Interpleader Act of 1926-44 Stat. 416 (repealed in 1936, ch. 13, $\$ 2,49$ Stat. 1097). d) Provisions for the Relief of Debtors Act (Frazier-Lemke Act) $\$ \S 75(\mathrm{n}), 75(\mathrm{o}), 47$ Stat. 1473 (1933), 11 U.S.C. $\$ 203$ (1964). Kalb v. Feuerstein, 308 U.S. 433 (1940). Although concerned with bankruptcy, $K a l b$ was not covered by the bankruptcy exception to $\$ 2283$ 's predecessor. Only in the case of the Interpleader Act did the language refer explicitly to the Judicial Code.

11 An examination of the cases cited by Mr. Justice Frankfurter, note 10 supra, indicates why he found it necessary to analyze them in terms of their "true rationale," the courts were not using his analytical terminology. For example, in Dietzsch $v$. Huidekoper, supra note 10, the Court said: "A court of the United States is not prevented from enforcing its own judgments by the statute which forbids it to grant a writ of injunction to stay proceedings in a State court." 103 U.S. at 497 . Since the 1948 revision (which produced the present anti-injunction statute), the removal provisions might better be characterized as exceptions in aid of the federal courts' jurisdiction than as "statutory" exceptions. See also Porter v. Dicken, 328 U.S. 252 (1946), which recognized an exception in the Emergency Price Control Act of 1942, $\$ 205$ (a), 56 Stat. 33. This later decision does not fit too neatly within Mr. Justice Frankfurter's pattern, since the provisions of that act and the application of the antiinjunction statute were not in direct conflict analytically.

12348 U.S. 511 (1955).

$13 I d$. at 515-16 (injunction not available even where, as federal courts see it, exclusive jurisdiction of the controversy is vested in the NLRB); accord, T. Smith \& Son v. Williams, 275 F.2d 397 (5th Cir. 1960) (injunction not available against compensation proceedings brought by a longshoreman against employer even though, 
Section 2283 speaks only to pending prosecutions. But as to threatened prosecutions, the statutory anti-injunction prohibition has had its counterpart in the judicially created "abstention" principle. This doctrine was forcefully enunciated in Douglas $v$. City of Jeannette. ${ }^{14}$ There the Supreme Court upheld a refusal to grant an injunction against threatened prosecution under an ordinance which it had that same day already held to be unconstitutional as applied in a similar factual situation. To deny relief in this situation, which involved first amendment rights and the application of an ordinance in a clearly unconstitutional way, was surely extreme. However, recent developments leave the status of the Donglas rule in doubt. In Dombroweski v. Pfister, ${ }^{15}$ a 1965 case, the Supreme Court held that abstention was improper where a statute was justifiably attacked as being on its face an overly broad regulation of activity protected by the first and fourteenth amendments. This amounts to saying that the state courts will not be permitted to construe such statutes by way of a criminal proceeding, since the very threat of prosecution under such vague provisions would emasculate the effectiveness of the constitutional protection involved. There are at least two possible constructions of Dombroweski: first, that it substantially modifies the doctrine of Douglas $v$. City of Jeannette; second, that it does not represent a departure in principle of any kind. ${ }^{16}$ Under the second view the factual context of Dombrowski made immediate relief absolutely essential, while that of Douglas did not. ${ }^{17}$

as federal courts see it, longshoreman's remedy is exclusively under federal Longshoreman's and Harbor Workers' Compensation Act). This rigid attitude is clearly articulated in Toucey v. New York Life Ins. Co., 314 U.S. 118 (1941) (injunction not available to prevent adjudication in state court of issue already litigated in federal court). The Toucey decision inspired the third exception clause now found in 28 U.S.C. \$2283 (1964). See 28 U.S.C.A. \$2283 (1964) (revisor's note).

14319 U.S. 157 (1943). See also Cleary v. Bolger, 371 U.S. 392 (1963); Pugach v. Dollinger, 365 U.S. 458 (1961); Stefanelli v. Minard, 342 U.S. 117 (1951); Watson v. Buck, 313 U.S. 387 (1941); Beal v. Missouri Pac. R.R., 312 U.S. 45 (1941).

15380 U.S. 479 (1965).

16 See Cameron v. Johnson, 381 U.S. 741 (1965) (per curiam).

17 Dombrowski involved broad gauged Louisiana "subversive activities" and "Communist propaganda" statutes which, the petitioners alleged, were being used as "part of a plan to employ ... threats of prosecution under color of the statutes to harass appellants and discourage them . . . from asserting and attempting to vindicate the constitutional rights of Negro citizens of Louisiana." The "overbreadth" of the statutes was alleged to render them "susceptible of sweeping and improper application abridging . . - [federally protected] rights." 380 U.S. at 482. Douglas involved the levying of fines on the unlicensed sale of literature, found to be unconstitutional as applied to Jehovah's Witness canvassers. The Dombroweski opinion seems to consider the broad wording of the Louisiana statutes, coupled with the allegation of their systematic application for harassment purposes, to be determinative:

But the allegations in this complaint depict a situation in which defense of the State's criminal prosecution will not assure adequate vindication of constitutional rights. They suggest that a substantial loss or impairment of freedoms of expression will occur if appellants must await the state court's disposition and ultimate review in this Court of any adverse determination.

These allegations, if true, clearly show irreparable injury.

Id. at 485-86. 
If the first view is correct, it may have significant implications for resolution of the section 2283 question. ${ }^{18}$ Even under the second view, in situations where the criminal prosecution is directed at activity which is clearly protected, the rationale of Dombrozeski may apply with equal force to section 2283 situations ; the possibly greater degree of intrusiveness would be balanced against the lack of any legitimate state interest in the proceedings. It is true that a threat of prosecution may be so intimidating that constitutional rights will not be exercised (thus never vindicated, and this at the option of the state officials), whereas once prosecution has been brought, the constitutional rights involved will be eventually vindicated. ${ }^{19}$ The answer to this argument is that speed is of the essence. It is not enough to know one has a right to service in a particular restaurant if, to vindicate that right, one must subject oneself to years of criminal litigation and its inherently vexatious incidents. ${ }^{20}$ The defendant in a pending action has, ex hypothesi, attempted to exercise his rights, but so did the plaintiffs in Dombrowssk ${ }^{21}$ thus the two situations (threatened versus pending prosecution) are not really distinguishable on this ground. ${ }^{22}$

It is within this context of a general reluctance to interfere in state court proceedings that the problem of the relationship between the antiinjunction statute and the civil rights legislation traditionally has been resolved. ${ }^{23}$ The 1871 law provides that: "Every person who, under color of any statute, ordinance, regulation, custom, or usage, of any State or Territory, subjects, or causes to be subjected, any citizen of the United States . . . to the deprivation of any rights, privileges, or immunities secured by the Constitution and laws, shall be liable to the party injured in an action at law, [or] suit in equity . . . ."24 The reluctance to act,

18 In Baines v. City of Danville, 337 F.2d 579 (4th Cir. 1964), cert. denied, 381 U.S. 939 (1965), the court relied to a great extent on pre-Dombrozess $i$ decisions in which $\$ 2283$ was not involved. See text accompanying notes 27-28 infra.

19 Even this is not guaranteed. See Amsterdam 798.

20 Id. at 796-99, 840-42.

21 Petitioners' organization was dedicated to the fostering of Negroes' civil rights. 380 U.S. at 482 .

${ }_{22} \mathrm{~A}$ second similarity to the $\$ 2283$ situation is the fact that although no prosecution had occurred, petitioners' offices had been searched and materials seized. Id. at 487-88.

23 It is a widely held belief that the intrinsic merit of both the statutory prohibition and the judicially recognized rule is in preserving the state court sphere from federal encroachment and in preventing friction between the two court systems. One may well doubt, however, whether the Act of 1793, discussed note 8 supra, was really a reflection of concern for harmonious federal-state relationships. Even according to Mr. Justice Frankfurter, the history of the Act of 1793 indicates that it was due more to a prevailing hostility to equitable remedies than to any fear of federal interference. Toucey v. New York Life Ins. Co., 314 U.S. 118, 131 (1941). See also Warren, New Light on the History of the Federal Judiciary Act of 1789, 37 HARV. L. REV. 49, 96-100 (1923).

24 Rev. Stat. \$ 1979 (1875), 42 U.S.C. § 1983 (1964). A cause of action bottomed on protected constitutional rights was characterized by the Supreme Court in Hague $\nabla$. CIO, 307 U.S. 496, 526 (1939), as extending "broadly to deprivation by state action of the rights, privileges and immunities secured to persons by the Constitution. It thus includes the Fourteenth Amendment and such privileges and immunities as are secured by the due process and equal protection clauses, as well as by the privileges and immunities clause of that Amendment." For a standard definition of "under color of law" see United States v. Classic, 313 U.S. 299, 326 (1941). 
at Ieast until very recently, under the 1871 law in situations where section 2283 is not involved has been matched by a refusal to find that the 1871 provision constitutes an exception to the anti-injunction statute. Only the Third Circuit Court of Appeals has made the affirmative finding that it is an exception. ${ }^{25}$ In that case, unfortunately, the court did not articulate its reasons. The Fourth, Sixth and Seventh Circuits have held that the 1871 law does not constitute an exception to section 2283.26 In Baines $v$. City of Danville ${ }^{27}$ the Court of Appeals for the Fourth Circuit pointed out that "creation of a general equity jurisdiction is in no sense antipathetic to statutory or judicially recognized limitations upon its exercise . . . . If every grant of general equity jurisdiction created an exception to the antiinjunction statute, the statute would be meaningless." 28 The court's search for a literal "incompatability" is quite consistent with the Toucey analysis. Thus far the Supreme Court has failed to clarify the situation, and has recently declined an opportunity to do so. 29

This is the muddled background against which the 1964 Civil Rights Act is now operating. In Dilworth $v$. Riner, ${ }^{30}$ a 1965 decision of great import, the Court of Appeals for the Fifth Circuit held that where the conduct subject to prosecution was clearly a protected activity under the guarantees of Title II, ${ }^{31}$ an injunction would lie under its remedial pro-

25 Cooper v. Hutchinson, 184 F.2d 119, 124 (3d Cir. 1950).

20 Baines v. City of Danville, 337 F.2d 579 (4th Cir. 1964), cert. denied, 381 U.S. 939 (1965); Wojcik v. Palmer, 318 F.2d 171 (7th Cir.), cert. denied, 375 U.S. 930 (1963); Goss v. Illinois, 312 F.2d 257 (7th Cir. 1963) ; Smith v. Village of Lansing, 241 F.2d 856 (7th Cir. 1957); Sexton v. Barry, 233 F.2d 220 (6th Cir.), cert. denied, 352 U.S. 870 (1956); Norwood v. Parenteau, 228 F.2d 148 (8th Cir.) (semble), cert. denied, 351 U.S. 955 (1955). See also Zellner v. Lingo, 218 F. Supp. 513 (M.D. Ala. 1963) (the court apparently ignored the anti-injunction statute); Island S.S. Lines, Inc. v. Glennon, 178 F. Supp. 292 (D. Mass. 1959) ; Aultman \& Taylor Co. v. Brumfield, 102 Fed. 7 (C.C.N.D. Ohio 1900), appeal dismissed on anthority of conusel for appellants, 22 Sup. Ct. 938 (1902); Hemsley v. Myers, 45 Fed. 283 (C.C.D. Kan. 1891).

27337 F.2d 579 (4th Cir. 1964), cert. denied, 381 U.S. 939 (1965).

28 Id. at 589.

20 Cameron v. Johnson, 381 U.S. 741 (1965) (per curiam). The Court remanded the case to the district court for a determination of the $\$ 2283$ issue.

30343 F.2d 226 (5th Cir. 1965).

$31 \$ \$ 201,202,78$ Stat. 243 (1964), 42 U.S.C. $\$ \$ 2000 \mathrm{a}, 2000 \mathrm{a}-1$ (1964). The facts were those of the hypothetical case which begins this Comment. The parties stipulated that the restaurant was an establishment covered by Title II. There is no doubt that the act would be a defense in state prosecutions of the type involved here in the ordinary process of trial and appeal. See 110 CoNG. REC. 9767 (1964) (remarks of Senator Humphrey). That, of course, is not the Dilworth case; what is involved there is an attempt to short circuit the entire process. The Supreme Court has declared that "sitting in" is as a matter of law a protected activity, i.e., a legitimate attempt to exercise rights secured by the act. Hamm v. City of Rock Hill, 379 U.S. 306, 311 (1964) : One can, however, imagine situations where the district court would first be required to make this finding. To one concerned with federal interference in the state sphere, the need to make such a finding might raise greater problems. It might have been difficult for the plaintiffs in Dilworth $v$. Riner to frame a complaint under the 1871 provision in terms of deprivation of due process or equal protection, although prosecution for activity, which cannot be a crime (Hamm v. City of Rock Hill, supra) would seem to be a denial of constitutional rights. The clause providing a remedy against deprivation of rights secured by the "laws" would seem to be a better vehicle. The first case involving that clause was 
visions. These are found in section 204 which provides: "(a) Whenever any person has engaged or there are reasonable grounds to believe that any person is about to engage in any act or practice prohibited by section 203, a civil action for preventive relief, including an application for a permanent or temporary injunction, restraining order, or other order, may be instituted by the person aggrieved...." 32 Section 203 provides:

No person shall (a) withhold, deny, or attempt to withhold or deny, or deprive or attempt to deprive, any person of any right or privilege secured by section 201 or 202 , or (b) intimidate, threaten, or coerce, or attempt to intimidate, threaten or coerce any person with the purpose of interfering with any right or privilege secured by section 201 or 202 , or (c) punish or attempt to punish any person for exercising or attempting to exercise any right or privilege secured by section 201 or $202 .^{33}$

There are two questions here: whether or not the court was correct in its assumption that sections 203 and 204 were meant to provide for civil actions against state officials; and whether or not the court was correct in its holding that those sections create an exception to the antiinjunction statute. The relationship between the two questions is slippery, for in one sense the resolution of the first (against what class of individuals does the act provide relief) must precede consideration of the second (does the act meet the "exception" requirements of section 2283), while in another sense the two questions are inseparable, since the recent legislation must be interpreted in light of the old.

The crucial words are "punish or attempt to punish" in section 203(c). Ordinarily, "punishment" is interpreted to mean a penalty inflicted by a political, military, or quasi-military unit for violation of its rules, on those subject to its authority and by virtue of such authority. ${ }^{34}$ However, the words could also reasonably be interpreted as referring to mere retaliatory violence or economic reprisal. Considered within the context of subsections (a) and (b), neither interpretation is clearly the more probable. ${ }^{35}$

apparently Bomar v. Keyes, 162 F.2d 136 (2d Cir.), cert. denied, 332 U.S. 825 (1947) (damages granted for wrongful discharge from employment, where absence was due to jury duty). Judge Hand's opinion implies that the 1871 law protects all rights granted by federal law except those which provide exclusive remedies for violation.

3278 Stat. 244 (1964), 42 U.S.C. \$2000a-3(a) (1964).

3378 Stat. 244 (1964), 42 U.S.C. $\$ 2000 \mathrm{a}-2$ (1964). (Emphasis added.) Sections 201 and 202 establish the right of equal access to public accommodations. 78 Stat. 243 (1964), 42 U.S.C. $\$ \$ 2000 \mathrm{a}, 2000 \mathrm{a}-1$ (1964).

34 For this interpretation where a somewhat similar problem was involved, see Fowler v. American Mail Line, Ltd., 69 F.2d 905 (9th Cir.), cert. denied, 293 U.S. 556 (1934).

35 In Hamm v. City of Rock Hill, 379 U.S. 306, 311 (1964), the Supreme Court said: "On its face, this language [section 203(c)] prohibits prosecution of any person for seeking service in a covered establishment, because of his race or color." The Court probably was not there interpreting the language to cover all situations, since the case involved the reversal of state convictions to which the guarantees of Title II were held to be a defense. 
However, subsection (c) (the "punish" clause) would appear to be superfluous if section 203 was intended to pertain only to action by private individuals motivated by private animus.

We now look to section 204. On the face of it, prosecution is certainly an attempt to punish (and thereby a violation of section 203), but the apparent difficulty comes in subsection (d) which provides:

In the case of an alleged act or practice prohibited by this title which occurs in a State, or political subdivision of a State, which has no State or local law prohibiting such act or practice, a civil action may be brought under subsection (a) : Provided, That the court may refer the matter to the Community Relations Service established by title $\mathrm{X}$ of this Act for as long as the court believes there is a reasonable possibility of obtaining voluntary compliance . . . . ${ }^{36}$

The language here seems to speak to civil actions against private individuals; it is rather odd to speak of referring "the matter to the Community Relations Service" and the "possibility of obtaining voluntary compliance" in the context of action against the state. Nevertheless, one could still conclude that while subsection 204(d) refers to violations of section 203 by private individuals acting in a private capacity, section 203 as a whole was meant to include all situations to which its language could reasonably apply. As to whether this or the opposite conclusion is the more reasonable, statutory language alone does not dictate an answer. ${ }^{37}$

The legislative history on this point is singularly unhelpful. ${ }^{38}$ The only remark of any possible pertinence was made by an opponent of the act:

As to State judges and State law enforcement officers, section 203 (c) provides that "no person shall (c) punish or attempt to punish any person for exercising or attempting to exercise any right or privilege secured by section 201 or 202." This is patently an attempt to make enforcement by State judges and State law enforcement officers of State laws which may later be held to conflict with the act a violation of a Federal law and to subject them to punitive Federal action. ${ }^{39}$

3678 Stat. 244 (1964), 42 U.S.C. $\$ 2000 \mathrm{a}-3$ (d) (1964).

37 For some persuasive arguments in support of the decision (particularly a study of the exact wording of some of the statutes found to be exceptions) see Brief for the United States as Amicus Curiae, Dilworth v. Riner, 343 F.2d 226 (5th Cir. 1965).

38 The House committee report is of no help in clarifying what was meant. The sectional analysis merely paraphrases the statutory language. H.R. REP. No. 914, 88th Cong., 2d Sess. 20-22 (1964). The House committee report discussed portions of the bill which, for purposes of this discussion, were substantially the same as the version finally passed. There was no Senate committee report since the bill was introduced in the Senate without first going through committee.

39110 CoNG. Rec. 7091 (1964) (remarks of Senator Stennis). An injunction is not a criminal penalty and the Senator's choice of words may conceivably have 
Since the resources of the states and their opportunities for harassment are infinitely greater than those of individuals, and since the possibility of state resistance in this form (i.e., arrest and prosecution) is not so obscure as reasonably to have been unforeseen, one can only speculate as to why none of the proponents of the act responded to the Senator's charge, The logic of the situation strongly suggests that no one responded because there was no answer: had this not been the meaning intended, the proponents of the act would at least have taken this opportunity to placate the conservative opposition. If, on the other hand, the issue was deliberately ignored, it would probably have been because the proponents did not wish to publicize the powerful potential of the provision. That the act does speak directly to the states in sections 201 and 202 is of no help in resolving the clause considered here, since those sections are purely definitional and were meant only to broaden the area of coverage. ${ }^{40}$

All these observations evince a pressing need for resolution by the Supreme Court. From the point of view of the Baines and Toucey analyses, it cannot be said that sections 203 and 204 are so clearly incompatible with the anti-injunction statute as necessarily to constitute an exception to it. Baines is persuasive in its denial of a clear incompatibility between the 1871 law and section 2283. Again, under these analyses, which assume an explicit awareness by Congress of the interpretative precedents of section 2283, a prohibition against punishment is probably not an indisputable manifestation of intent to authorize an exception to section 2283. But the Court should do more; it should reexamine the adequacy of these analyses. The Court must make basic policy decisions about the federal system when it decides whether to require a strong showing of intent to carve out an exception or a literal necessity for finding an exception, or whether to turn the analysis around and phrase the test in terms of frustration versus effectuation of the basic purposes of the civil rights legislation. ${ }^{41}$ The traditional analysis makes the solution fairly mechanical. The alternative technique still leaves much to be decided; the solution depends on further conclusions about the nature of the rights granted and protected by the two statutes, on conclusions about how valuable they are and thus, essentially, upon how great the need for anticipatory jurisdiction is. It seems beyond contention that the need here is very great indeed.

If the power to stay pending prosecutions is found under either the 1871 or the 1964 act, it need not be a radically disruptive mechanism. Its

rendered the remark so preposterous that no one thought a response necessary. It is also possible that Senator Stennis was actually talking about a prosecution under 18 U.S.C. \$242 (1964). See, e.g., Screws v. United States, 325 U.S. 91 (1945). But if this is what he meant, it is hard to see why he referred explicitly to subsection 203(c), since persons acting under color of law would be liable for deprivation of rights without this explicit $\$ 203$ (c) prohibition.

40 See, e.g., 110 CoNG. REc. 6534 (1964) (remarks of Senator Humphrey). For a clearly untenable interpretation see Tyson v. Cazes, 238 F. Supp. 937 (E.D. La. 1965).

41 See 1A Moore, Federal Practice $\Uparrow 0.213$ [2] (2d ed. 1965). 
availability could be severely limited to those cases, like Dilworth, where there clearly has been no criminal conduct, i.e., where no possible findings of fact could change that legal conclusion, and where therefore the state has no legitimate interest whatever in the proceeding. But, whatever the resolution of the problem, the political and social implications of this issue make it imperative that either the federal injunctive power be enunciated or that its absence be made very clear. 